\title{
A Novel Process for Extracting Precious Metals from Spent Mobile Phone PCBs and Automobile Catalysts
}

\author{
Byung-Su Kim*, Jae-Chun Lee, Jinki Jeong, Dong-Heo Yang, Doyun Shin and Kang-In Lee \\ Korea Institute of Geoscience and Mineral Resources (KIGAM), Mineral Resources Research Division, Rare Metals Research Center, \\ Urban Mine Research Team, 124 Gwahang-no, Yuseong-gu, Daejeon 305-350, Korea
}

A novel process to simultaneously extract the precious metals such as gold, silver, platinum, palladium and rhodium from spent mobile phone printed circuit boards (PCBs) and honeycomb-type auto catalysts by smelting using waste-copper slag without adding any collector metals or by-products such as dross, matte and slime has been developed. In the process, waste-copper slag which is an industrial waste discharged from copper smelter is used not only as a flux for controlling slag composition, but also as a collector metal for capturing precious metals, and a plastic component contained in spent mobile phone PCBs is done as a reducing agent of iron oxides contained in the waste-copper slag. Using the developed process, up to $95 \%$ of gold, silver, platinum, palladium and rhodium contained in the raw materials were extracted in a $\mathrm{Cu}-\mathrm{Fe}-\mathrm{Sn}$ alloy phase, respectively. [doi:10.2320/matertrans.M2013051]

(Received February 5, 2013; Accepted March 19, 2013; Published April 26, 2013)

Keywords: precious metals, spent mobile phone printed circuit boards (PCBs), spent honeycomb-type auto catalysts, smelting, waste-copper slag, recycling

\section{Introduction}

Large amounts of spent printed circuit boards (PCBs) and honeycomb-type auto catalysts are generated, respectively, from mobile phones and automotive catalytic converters. The environmental pollution caused thereby becomes a social issue. However, the spent PCBs and auto catalysts contain precious metals such as gold, silver, platinum, palladium and rhodium that can be recovered. It has been known that the total amount of precious metals contained in spent mobile phone PCBs is 700-4,000 ppm, and that in spent auto catalysts is $1,000-2,000 \mathrm{ppm}^{1-5)}$ In addition, the spent PCBs contains significant amounts of valuable metals like copper, tin and iron. ${ }^{1-5)}$ Thus, recovering such precious metals is strongly required in terms of effective utilization of resources and environmental conservation. Currently, a number of processes for extracting precious metals from the solid wastes have been suggested and developed. These are largely divided into gas phase volatilization, hydrometallurgical and pyrometallurgical processes.

In the gas phase volatilization process, precious metals from spent auto catalysts are volatilized by selective chlorination and condensed in a cooler zone. Most of the volatilization reactions are carried out in the temperature range of 523-873 $\mathrm{K}^{6,7)}$ The hydrometallurgical process is to leach precious metals from spent PCBs and auto catalysts by using acid or alkali solutions and concentrate them from the leach solution by using various methods like precipitation, cementation and solvent extraction.,7) In the pyrometallurgical process, spent auto catalysts are melted with flux components and contact the molten slag containing precious metals with a molten metal pool, into which the precious metals dissolve and accumulate. The molten metal is called a collector metal. Iron, copper, nickel, lead-copper and nickel matte are commonly used as collector metals. ${ }^{6,7)}$ The extracted precious metals must be further treated in order to individually separate and purify them. Recently, several

${ }^{*}$ Corresponding author, E-mail: bskim@kigam.re.kr

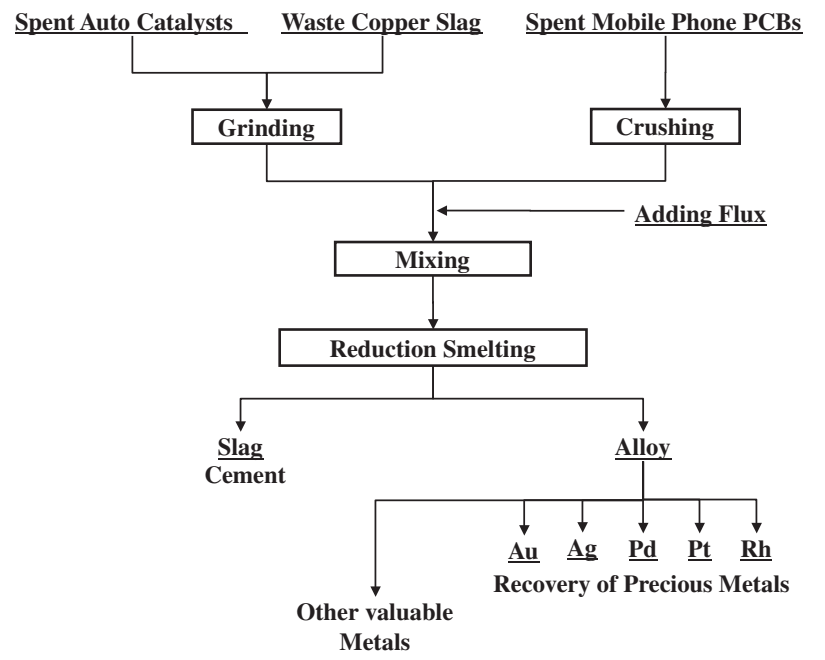

Fig. 1 Flow sheet of the process developed in the study.

pyrometallurgical processes that employ the nonferrous metal smelting furnaces are developed and commercialized. The processes are to extract precious metals as a nonferrous metal phase from spent PCBs and auto catalysts charging in the furnaces them together with nonferrous concentrate or byproducts such as dross, matte and slime. ${ }^{8,9)}$ In the processes, the extracted precious metals are also further treated in order to individually separate and purify them.

Among the above processes, the pyrometallurgical processes are effective for extracting precious metals from the solid wastes in a large-scale treatment. However, a process that can extract precious metals from spent PCBs and auto catalysts by using waste nonferrous slag without adding any collector metals or byproducts such as dross, matte and slime has not yet been developed. The present research is concerned with developing such a new process. Figure 1 shows the flow sheet of the developed process. In the present process, waste-copper slag which is an industrial waste discharged from copper smelter can be used not only as fluxes for controlling slag composition, but also as a collector 
Table 1 Chemical composition of spent mobile phone printed circuit boards (PCBs).

\begin{tabular}{cc}
\hline Element & Concentration (mass\%) \\
\hline $\mathrm{Au}$ & 0.1359 \\
$\mathrm{Ag}$ & 0.2262 \\
$\mathrm{Pd}$ & 0.0096 \\
$\mathrm{Pt}$ & 0.0036 \\
$\mathrm{Rh}$ & 0.0005 \\
$\mathrm{Cu}$ & 42.8 \\
$\mathrm{Fe}$ & 4.6 \\
$\mathrm{Sn}$ & 2.6 \\
$\mathrm{Ni}$ & 0.6 \\
$\mathrm{~Pb}$ & 0.06 \\
$\mathrm{Zn}$ & 0.01 \\
$\mathrm{Co}$ & 0.01 \\
$\mathrm{Al}_{2} \mathrm{O}_{3}$ & 4.2 \\
$\mathrm{SiO}$ & 10.0 \\
$\mathrm{CaO}$ & 2.7 \\
$\mathrm{MgO}_{2}$ & 0.4 \\
\hline
\end{tabular}

Table 2 Chemical composition of spent honeycomb-type auto catalysts.

\begin{tabular}{cc}
\hline Element & Concentration (mass\%) \\
\hline $\mathrm{Pd}$ & 0.08 \\
$\mathrm{Pt}$ & 0.07 \\
$\mathrm{Rh}$ & 0.01 \\
$\mathrm{Al}_{2} \mathrm{O}_{3}$ & 37.8 \\
$\mathrm{SiO}_{2}$ & 34.6 \\
$\mathrm{CaO}$ & 0.8 \\
$\mathrm{MgO}$ & 9.2 \\
\hline
\end{tabular}

metal for capturing precious metals, and a plastic component contained in spent PCBs can be used as a reducing agent. It was thus thought that the developed process is simple and economic compared with the conventional pyrometallurgical processes.

\section{Experiment}

\subsection{Choice of slag system}

Tables 1 and 2 present the chemical compositions of the spent mobile phone PCBs and auto catalysts, used in the work. The samples were respectively obtained from spent mobile phones and automotive catalytic converters. Figure 2 shows the liquidus line at $1673 \mathrm{~K}$ of the ternary slag system consisting of the three main slag components contained in the spent PCBs. The dot in the figure represents the weightpercent composition based on the total mass of just the three main slag-forming oxides contained in the spent PCBs. As shown in Fig. 2, the melting temperature of the spent PCBs is expected to be over $1673 \mathrm{~K}$. It was reported by previous researchers that the melting temperature of the spent auto catalysts is over $1873 \mathrm{~K}^{5}$ ) Such high melting temperature means that a lot of energy is necessary to dissolve and accumulate the precious metals contained in the spent PCBs and auto catalysts into a molten metal pool. Thus, suitable

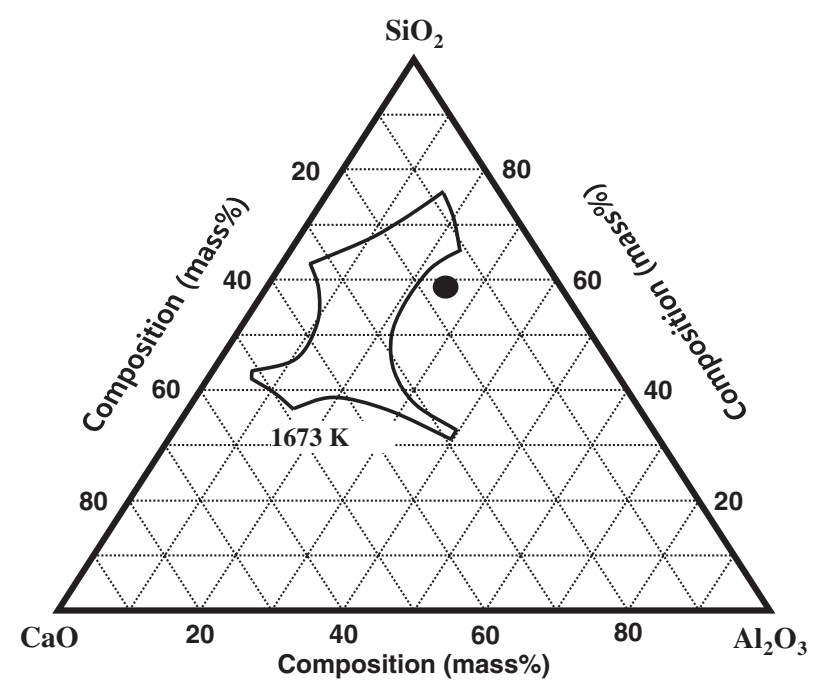

Fig. 2 Liquidus line at $1673 \mathrm{~K}$ of the $\mathrm{Al}_{2} \mathrm{O}_{3}-\mathrm{CaO}-\mathrm{SiO}_{2}$ slag system used to predict the melting temperature of the spent mobile phone PCBs. The dot represents the mass \% composition based on the total mass of just the three main slag-forming oxides contained in the used PCBs (Table 1).

Table 3 Chemical composition of waste-copper slag.

\begin{tabular}{cc}
\hline Element & Concentration (mass\%) \\
\hline $\mathrm{Cu}$ & 0.7 \\
$\mathrm{FeO}$ & 47.9 \\
$\mathrm{Al}_{2} \mathrm{O}_{3}$ & 4.1 \\
$\mathrm{SiO}_{2}$ & 34.5 \\
$\mathrm{CaO}$ & 3.4 \\
$\mathrm{MgO}$ & 1.2 \\
\hline
\end{tabular}

fluxes are needed to lower their melting temperatures. However, the additional amounts of fluxes must be as small as possible, because it is undesirable to generate large amounts of waste solids that require disposal.

With this in mind, an $\mathrm{FeO}-\mathrm{CaO}-\mathrm{SiO}_{2}$ slag system was chosen to simultaneously extract precious metals such as $\mathrm{Au}$, $\mathrm{Ag}, \mathrm{Pd}, \mathrm{Pt}$ and $\mathrm{Rh}$ from the spent PCBs and auto catalysts by smelting with adding waste-copper slag as a slag formative while minimizing the additional amount of fresh slag formatives. Table 3 presents the chemical composition of the waste-copper slag used in this work. The waste slag was obtained from LS-Nikko copper smelter INC. in Korea. Currently, large amount of the waste slag has been discarded from the slag cleaning furnace of copper smelting furnace. It is thus desirable to reuse the waste-copper slag in the viewpoint of resource recycling. Figure 3 shows the liquidus line of the waste-copper slag system at $1573 \mathrm{~K}$. Also displayed in this figure is the target composition region that will be used to calculate the input ratio of spent PCBs, spent auto catalysts, and fluxes in the reduction smelting step.

\subsection{Experimental procedure}

Reduction smelting experiments were carried out in a box type furnace described in previous paper. ${ }^{5)}$ Waste-copper slag and spent auto catalysts were first crushed into small particles with a diameter of from 0.5 to $1.0 \mathrm{~cm}$, respectively. Spent 


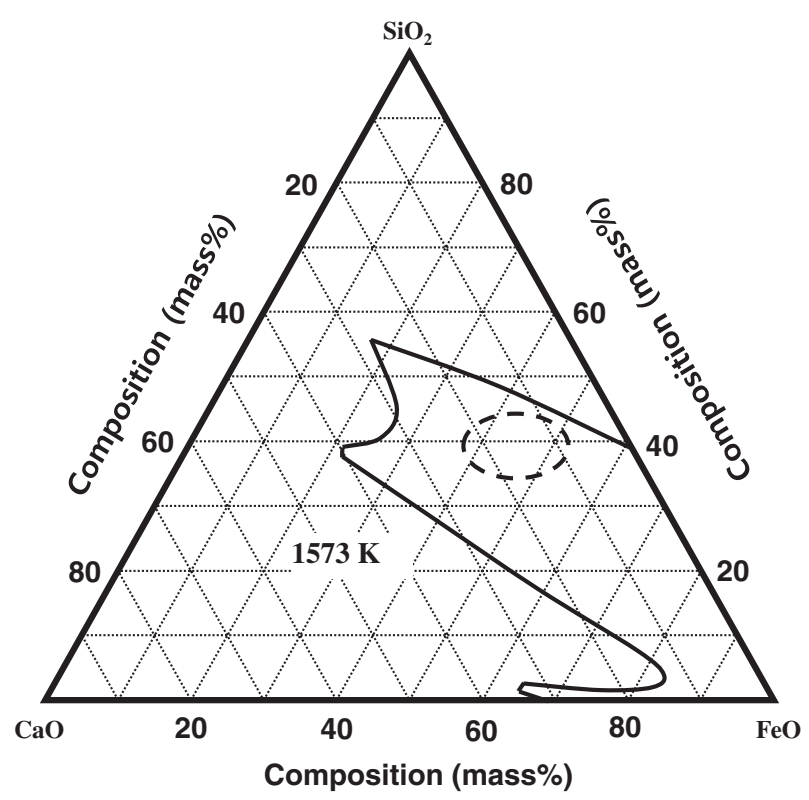

Fig. 3 Liquidus line at $1573 \mathrm{~K}$ of $\mathrm{FeO}-\mathrm{CaO}-\mathrm{SiO}_{2}$ slag system which is the waste-copper slag system. Circle with dotted line represents the target composition region that will be used to calculate the input ratio of spent mobile phone PCBs, spent auto catalysts and waste-copper slag in the reduction smelting step.

Table 4 Input amounts of raw materials tested for the reduction smelting.

\begin{tabular}{ccccc}
\hline & \multicolumn{4}{c}{ Amount of species (g) } \\
\cline { 2 - 5 } Sample No. & $\begin{array}{c}\text { Spent mobile } \\
\text { phone PCBs }\end{array}$ & $\begin{array}{c}\text { Spent auto } \\
\text { catalyst }\end{array}$ & $\begin{array}{c}\text { Waste-copper } \\
\text { slag }\end{array}$ & $\mathrm{CaO}$ \\
\hline A & 100 & 30 & 150 & 30 \\
B & 100 & 50 & 150 & 50 \\
C & 100 & 100 & 150 & 70 \\
\hline
\end{tabular}

PCBs are also crushed under $5 \mathrm{~cm}$ to insert easily into a melting crucible. The waste-copper slag, spent PCBs and auto catalysts were then mixed with $\mathrm{CaO}$ which is a flux as an agent for controlling slag composition. Here, $\mathrm{CaO}$ used in the experiments was analytical grade manufactured by Junsei Chemical Company. The addition amounts of $\mathrm{CaO}$ were calculated by considering the chemical compositions of $\mathrm{FeO}$, $\mathrm{CaO}$ and $\mathrm{SiO}_{2}$ contained in the spent PCBs, auto catalysts and waste-copper slag to achieve the target slag composition region shown in Fig. 3. Here, the reduction agents such as coal and coke were not added because spent PCBs contains considerable amount of plastic which can be used to maintain the reduction atmosphere of furnace during the smelting. The mixture was charged in an alumina crucible $(10 \mathrm{~cm}$ height and $7 \mathrm{~cm}$ inner diameter), and fed to the reactor in the furnace. In the experiment, the range of $310-420 \mathrm{~g}( \pm 2 \mathrm{~g})$ of the mixed solids was used for each run. Table 4 presents the input amount of raw materials tested for the reduction smelting. The mixture started melting at around $1473 \mathrm{~K}$, and was fully melted at $1573 \mathrm{~K}$ for $1200 \mathrm{~s}$. And then, the reduction smelting was carried out at the range of 1623$1698 \mathrm{~K}$ for $3600 \mathrm{~s}$ to obtain a melt. After that, the melt was cooled in air. During the experiments, it was not possible to avoid partial erosion of the crucible.
Table 5 Average chemical compositions of slags obtained from the charge materials under the reduction smelting temperature between 1623 and $1698 \mathrm{~K}$.

\begin{tabular}{|c|c|c|c|c|c|c|c|}
\hline \multirow{2}{*}{ Sample No. } & \multirow{2}{*}{$\begin{array}{c}\text { Temp. } \\
(K)\end{array}$} & \multicolumn{6}{|c|}{ Concentration (mass $\%$ ) } \\
\hline & & $\mathrm{Al}_{2} \mathrm{O}_{3}$ & $\mathrm{CaO}$ & $\mathrm{FeO}$ & $\mathrm{Fe}_{2} \mathrm{O}_{3}$ & $\mathrm{MgO}$ & $\mathrm{SiO}_{2}$ \\
\hline A & $1623-1698$ & 11.1 & 17.2 & 18.2 & 7.4 & 2.0 & 32.8 \\
\hline B & 1673 & 12.0 & 22.7 & 14.2 & 6.5 & 2.8 & 33.3 \\
\hline $\mathrm{C}$ & 1673 & 15.1 & 24.3 & 11.8 & 5.2 & 3.7 & 30.4 \\
\hline
\end{tabular}

Table 6 Mass and chemical compositions of alloys obtained from the charge materials under the reduction smelting temperature between 1623 and $1698 \mathrm{~K}$.

\begin{tabular}{|c|c|c|c|c|c|c|c|c|c|c|c|}
\hline \multirow{3}{*}{$\begin{array}{c}\text { Sample } \\
\text { No. }\end{array}$} & \multirow{3}{*}{$\begin{array}{c}\text { Temp. } \\
(K)\end{array}$} & \multirow{3}{*}{$\begin{array}{c}\text { Mass } \\
\text { of } \\
\text { Alloy } \\
\text { (g) }\end{array}$} & \multicolumn{9}{|c|}{ Concentration } \\
\hline & & & $\mathrm{Cu}$ & $\mathrm{Fe}$ & $\mathrm{Sn}$ & $\mathrm{Ni}$ & $\mathrm{Au}$ & $\mathrm{Ag}$ & $\mathrm{Pd}$ & $\mathrm{Pt}$ & $\mathrm{Rh}$ \\
\hline & & & \multicolumn{4}{|c|}{$\operatorname{mass} \%$} & \multicolumn{5}{|c|}{ ppm } \\
\hline \multirow{3}{*}{ A } & 1623 & 65.1 & 64.1 & 23.1 & 4.4 & 2.2 & 1880 & 3300 & 450 & 440 & 110 \\
\hline & 1673 & 68.4 & 60.1 & 30.8 & 4.0 & 2.1 & 1800 & 2350 & 450 & 380 & 120 \\
\hline & 1698 & 69.1 & 60.5 & 30.3 & 3.9 & 2.4 & 1800 & 2900 & 440 & 380 & 95 \\
\hline B & 1673 & 65.8 & 59.5 & 32.2 & 5.0 & 2.3 & 1600 & 3450 & 930 & 430 & 170 \\
\hline $\mathrm{C}$ & 1673 & 70.6 & 57.0 & 33.7 & 5.2 & 2.4 & 1400 & 3400 & 1350 & 780 & 310 \\
\hline
\end{tabular}

Samples before and after the reduction smelting were analyzed for $\mathrm{Au}, \mathrm{Ag}, \mathrm{Pd}, \mathrm{Pt}, \mathrm{Rh}, \mathrm{Cu}, \mathrm{Sn}, \mathrm{Ni}, \mathrm{Al}, \mathrm{Ca}$ and $\mathrm{Mg}$ by the inductively coupled plasma (ICP) method (JY-38 Plus, Jobin-Yvon Equipment Co., London, UK). Also, the total iron and divalent iron contents in the slag specimens were determined by titration with $\mathrm{K}_{2} \mathrm{Cr}_{2} \mathrm{O}_{7}$, the $\mathrm{SiO}_{2}$ content by a gravimetric analysis method.

In the present study, the extraction ratios of gold, silver, platinum, palladium and rhodium were defined as:

$$
E_{\mathrm{M}}=\frac{A_{\mathrm{M}}}{\left(A_{\mathrm{M}}+S_{\mathrm{M}}\right)} \times 100
$$

where, $E_{\mathrm{M}}$ is the extraction ratio of $\mathrm{M}$ metal, $A_{\mathrm{M}}$ is the weight (g) of $\mathrm{M}$ metal concentrated into the molten metal phase (alloy phase), and $S_{\mathrm{M}}$ is the weight ( $\mathrm{g}$ ) of $\mathrm{M}$ metal remained in the slag phase.

\section{Results and Discussion}

Table 5 presents the chemical composition of the slags obtained from the experiments. Although the viscosity of the slag was not measured in this study, it was estimated to be about 4 poise at $1673 \mathrm{~K}$ based on previously reported data. ${ }^{10)}$ Thus, all the molten phases obtained in this work were easily separated into slag and alloy phases.

Table 6 presents the mass and chemical compositions of the alloy phases obtained from the experiments. As shown in Table 6, the alloy phase was mainly composed of copper, iron and tin with small amounts of $\mathrm{Au}, \mathrm{Ag}, \mathrm{Pt}, \mathrm{Pd}$ and $\mathrm{Rh}$. Here, most iron in the alloy phase was reduced from iron oxide compounds contained in the waste-copper slag by a plastic component contained in the spent PCBs. It was verified that the average reduction ratio of the iron oxide compounds is about $29.5 \%$. 


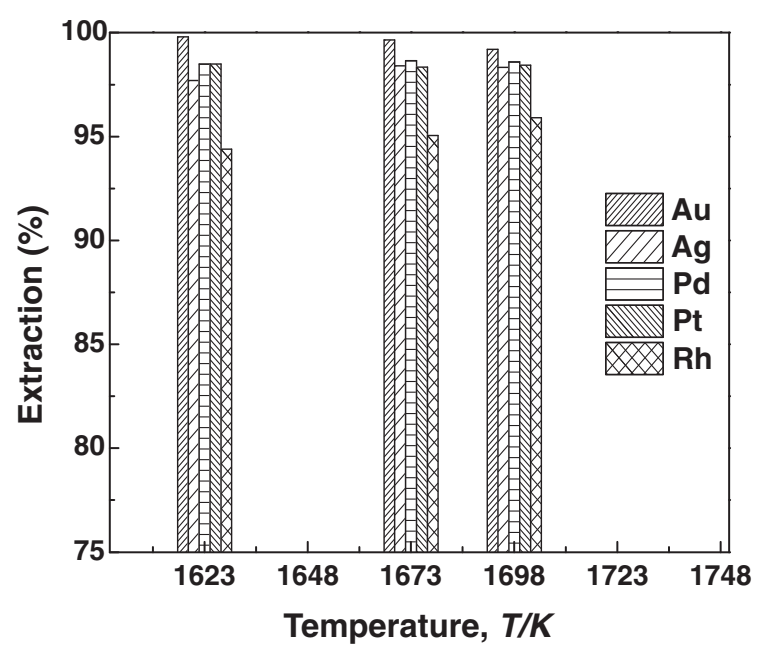

Fig. 4 Average recovery percentage of $\mathrm{Au}, \mathrm{Ag}, \mathrm{Pd}, \mathrm{Pt}$ and $\mathrm{Rh}$ extracted from the charge material of $\mathrm{A}$ in Table 4.

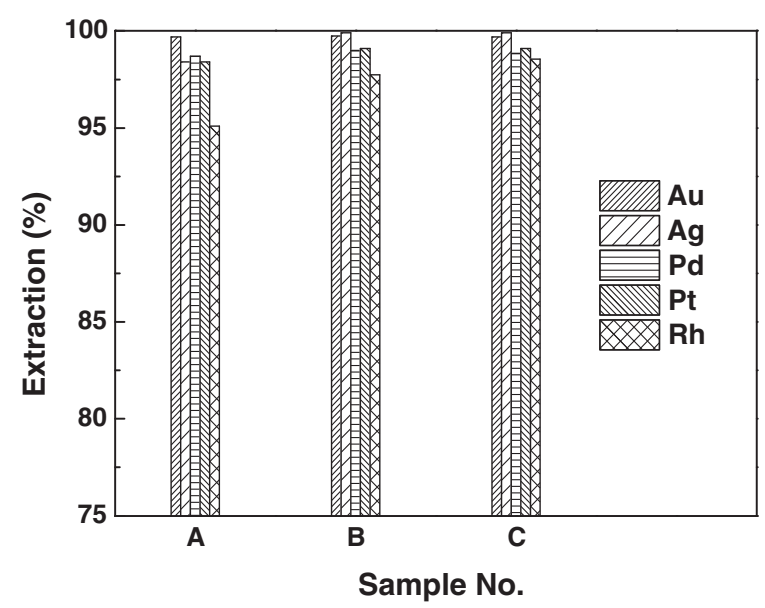

Fig. 5 Average recovery percentage of $\mathrm{Au}, \mathrm{Ag}, \mathrm{Pd}, \mathrm{Pt}$ and $\mathrm{Rh}$ extracted from the charge materials in Table 4 under a reduction smelting temperature of $1673 \mathrm{~K}$.

The effect of reduction smelting temperature on the recovery percentages of $\mathrm{Au}, \mathrm{Ag}, \mathrm{Pt}, \mathrm{Pd}$ and $\mathrm{Rh}$ was examined by varying the temperature between 1623 and $1698 \mathrm{~K}$, while the mixing ratio was kept constant. Figure 4 presents the effect of reduction smelting temperature on the recovery percentages using sample A shown in Table 4. It is seen in the figure that the recovery percentages were over $95 \%$ for all precious metals considered at over $1673 \mathrm{~K}$ and recovery percentages is relatively steady at the considered temperature range.

The effect of the input amount of auto catalysts on the recovery percentages of $\mathrm{Au}, \mathrm{Ag}, \mathrm{Pt}, \mathrm{Pd}$ and $\mathrm{Rh}$ was examined by varying the input amount between 30 and $100 \mathrm{~g}$, while the reduction smelting temperature was kept constant. Figure 5 presents the effect of the input amount on the recovery percentages of $\mathrm{Au}, \mathrm{Ag}, \mathrm{Pt}, \mathrm{Pd}$ and $\mathrm{Rh}$ under a reduction smelting temperature of $1673 \mathrm{~K}$. These results show that $\mathrm{Au}$, $\mathrm{Ag}, \mathrm{Pt}, \mathrm{Pd}$ and $\mathrm{Rh}$ are predominantly collected in the alloy phase, and the recovery percentages are over $95 \%$ under all the mixing ratios considered. Also, it is noted that the recovery percentages is not changed with increasing the input amount of auto catalysts.

It was thus verified that the novel process to extract precious metals contained in spent mobile phone PCBs and honeycomb-type auto catalysts by reduction smelting using waste-copper slag without adding any collector metals or byproducts such as dross, matte and slime is possible. The main feature of the process is that waste-copper slag is used not only as a flux for controlling slag composition, but also as a collector metal for capturing precious metals, and a plastic component contained in spent mobile phone PCBs is done as a reducing agent of iron oxides contained in the waste-copper slag.

Therefore, the proposed process is simpler than conventional processes, and has an additional benefit of recovering other valuable metals like copper, tin and iron from spent mobile phone PCBs and waste-copper slag.

\section{Conclusions}

In this study, a novel process to extract precious metals contained in spent mobile phone PCBs and honeycomb-type auto catalysts by smelting without collector metals with using only $\mathrm{CaO}$ as a slag formative was investigated. Based on the experimental results, a novel process flow-sheet was proposed. In the reduction smelting process over $95 \%$ of gold, silver, platinum, palladium and rhodium contained in the spent PCBs and auto catalysts were respectively extracted in a $\mathrm{Cu}-\mathrm{Fe}-\mathrm{Sn}$ alloy phase at the reduction smelting temperature of over $1673 \mathrm{~K}$ under all the mixing ratios considered. The proposed novel process is thus simpler than conventional processes as there is no requirement of collector metals like dross, matte and slime used in conventional pyrometallurgical processes.

\section{Acknowledgement}

This research was supported by the Basic Research Project of the Korea Institute of Geoscience and Mineral Resources (KIGAM) funded by the Ministry of Knowledge Economy of Korea.

\section{REFERNCES}

1) LS-Nikko Copper Inc., Uljin-gun, Ulsan, Korea, private communication (April 2012).

2) Onsan Refinery, Uljin-gun, Ulsan, Korea, private communication (May 2012).

3) J. E. Hoffmann: JOM 44 (1992) 43-48.

4) M. Benson, C. R. Bennett, J. E. Harry, M. K. Patel and M. Cross: Resour. Conserv. Recycling 31 (2000) 1-7.

5) B. S. Kim, J. C. Lee, S. P. Seo, Y. K. Park and H. Y. Sohn: JOM 56 (2004) 55-58

6) J. Shibata and A. Okuda: J. MMIJ 118 (2002) 1-8.

7) J. W. Ahn, J. G. Ahn and M. S. Lee: J. Korean Inst. Metall. Mater. 40 (2002) 116-121.

8) http://www.dowa-eco.co.jp/en/recycle.html.

9) C. E. M. Meskers, C. Hageluken and G. V. Damme: EPD Congress, ed. by Stanley M. Howard, (Warrendale, PA: TMS, 2009) pp. 11311136.

10) M. Allivert, et al:: SLAG ATLAS, (Germany: Verlag Stahleisen GmbH, 1995) p. 206. 